Bangladesh J. Bot. 43(3): 261-265, 2014 (December)

\title{
EFFECTS OF DEFOLIATION ON PHOTOSYNTHESIS, DRY MATTER PRODUCTION AND YIELD IN SOYBEAN
}

\author{
Md TARIQUl ISLAM* \\ Crop Physiology Division, Bangladesh Institute of Nuclear Agriculture (BINA), \\ Mymensingh-2202, Bangladesh
}

Key words: Defoliation, Dry matter, Photosynthesis, Soybean yield

\begin{abstract}
Two pot experiments were conducted to assess the effect of various degree of defoliation on photosynthesis, dry matter production and yield in soybean. Defoliation significantly increased rate of photosynthesis and transpiration and leaf conductance of the soybean genotypes however, it decreased dry matter production and yield.

\section{Introduction}

Soybean (Glycine max (L.) Merr.) yield can be either source- or sink limited, depending on the assimilatory capacity of the mother plant to the assimilate demands of the developing seeds (Proulx and Naeve 2009). Yield is the manifestation of various physiological processes occurring in plants and they are usually modified by management practices. Yield was increased in branching type sesame with clipping at 35 DAS (Kokilavani et al. 2007) and in mustard with defoliation at 40 - 85 DAS (Chhabra et al. 1996). In some situations, physical leaf area is adequate and even more than required, but the functional efficiency is far lower due to utilizing resources as a respiratory burden of excessive leaves (Venkateswarlu and Visperas 1987). Negative effect of defoliation was reported in non-branching type of sesame (Tewolde et al. 1994, Islam 2010, Banks and Bernardi 1987).

The effect of manipulation of source (leaf) size in legumes were reported to be both advantageous and disadvantageous in many crops (Board and Harville 1998, Bhatt and Rao 2003, Hossain et al. 2006, Abdi et al. 2007, Barimavandi et al. 2010). One-third leaf removal from basal portion of the canopy in cowpea increased grain yield over control and severe defoliation decreased seed yield (Hossain et al. 2006, Gustafson et al. 2006). Likewise, mild defoliations (16.6 - 20\%) during reproductive phase did not adversely affect seed yield in soybean (Board and Harvelle 1998) and in mungbean (Pandey and Singh 1984, Begum et al. 1997). Reverse results of defoliation was also reported in soybean (Verma et al. 1992, Borras et al. 2004), in cowpea (Pandey 1983) and in mungbean (Rao and Ghildiyal 1985). In tropical and sub-tropical countries, foliage loss by insects and diseases is common in soybean and mungbean yet they can sustain such source (leaf) damages up to a certain extent without significant yield loss. Defoliation caused by insect pests is notoriously difficult to estimate and sometimes over estimated. Here, yield loss assessment in soybean with artificial defoliation at various degrees was studied. Unless severe, vegetative stages usually does not cause yield loss in soybean, but reproductive stages are more sensitive, this study was thus carried out to investigate the effect of the magnitude and positions of leaf removal during the beginning of reproductive phase on photosynthesis, dry matter production, yield attributes and yield in soybean.
\end{abstract}

*Author for correspondence: <islamtariqu105@yahoo.com> 


\section{Materials and Methods}

Two experiments were conducted at the pot yard of Bangladesh Institute of Nuclear Agriculture (BINA), Mymensingh $\left(24^{\circ} 8^{\prime} \mathrm{N} 90^{\circ} 0^{\prime}\right.$ E), Bangladesh during January - May, 2010 and 2011. Four soybean genotypes viz. BARI Soybean-5, BAU Soybean-109, AVRDC Soybean-78 and BAU Soybean-147 were subjected to different defoliation treatments viz. control (undefoliated), $50 \%$ basal leaf defoliation, $100 \%$ defoliation, $50 \%$ defoliation of top leaves, defoliation of top four leaves, defoliation of top three leaves, defoliation of top two leaves and defoliation of top one leaf. The experiment was laid out in complete randomized design with four replications. Additional 24 pots were taken to grow six plants of each genotype for leaf area calculation. Several seeds were sown in plastic pots containing $8 \mathrm{~kg}$ soils (Silty loam, organic matter $1.05 \%$, total N $0.07 \%$, available P 14.3 ppm, exchangeable K 0.25 meq. per 100 g soil, available S 13.2 and soil pH 6.67). Finally one plant was allowed to grow in each pot. Urea, triple superphosphate and muriate of potash were used as a source of nitrogen, phosphorus and potassium at the rate of $1.66,2.82$ and $1.16 \mathrm{~g} /$ pot, respectively, corresponding dose of 50,85 and $35 \mathrm{~kg} / \mathrm{ha}$, respectively, at the time of final pot preparation. Considering total leaf area/plant as hundred per cent, contribution of leaf area at each nodal position in the main stem was estimated. Leaf in the branches, initiated in a particular node was included in that nodal position of the main stem. Contribution of individual nodal leaf area to total leaf area/plant was estimated. To defoliate leaf at different degrees, complete compound leaf and/ or leaves, and sometimes one or two leaflets or even a portion of a leaflet were clipped off. Leaf area of top one compound leaf represented about $6-10 \%$ of the total leaf area/plant measured in automatic leaf area meter (model: LI 2000, LI-COR Inc., Lincoln, NE, USA). Cultural practices were done as and when required. Defoliation treatments were imposed at 53 DAS. Data on photosynthetic parameters were measured at 60 DAS using Portable Photosynthesis System LI-6400XT, LI-COR Inc., Lincoln, NE, USA. Dry mass and yield attributes were taken at maturity. All data were analyzed statistically as per the used design following the analysis of variance (ANOVA) technique and the mean differences were adjusted with DMRT using the statistical computer package program, MSTAT-C.

\section{Results and Discussion}

Results showed that all defoliation treatments significantly increased photosynthesis and transpiration rate of the soybean genotypes (Table 1). Leaf conductance was also increased due to defoliation treatments except defoliation of top one leaf. These results are in conformity with Bernacchi et al. (2007) who observed that transpiration was proportional to leaf conductance in soybean under constant environmental conditions. Significant variation was not observed in photosynthesis in top one leaf-defoliated plant as compared to control. These results are in conformity with Verma et al. (1992) and Board and Harville (1998) who observed that partial defoliation during flowering and seed filling had no adverse effects on seed yield because of $\leq 20$ $33 \%$ defoliation at flower initiation phase attains capacity to compensate leaf loss and reached leaf area $\geq 4$ immediately after imposed treatment through re-growth of leaves in soybean. In the current investigation, defoliation of top 1 or 2 leaves showed superiority in seed yield compared to other treatments because of higher total dry matter, greater number of pods and seeds. The highest photosynthesis, leaf conductance and transpiration rate were observed in the regenerated leaves after $100 \%$ defoliation followed by $50 \%$ defoliation of top leaves. BARI Soybean-5 showed higher photosynthetic rate compared to others. Similarly, the high sink-source ratio caused by defoliation increased the photosynthetic rates in the remaining leaves in okra, mungbean, soybean and groundnut (Bhatt and Rao 2003, Pandey and Singh 1984, Chen and Lia 1991, Ghosh and Sengupta 1986). Total dry matter production was affected by the defoliation treatments (Table 2). 
Table 1. Effects of defoliation of soybean genotypes on photosynthesis, leaf conductance and transpiration rate.

\begin{tabular}{lccc}
\hline Treatment & $\begin{array}{c}\text { Photosynthetic rate } \\
\left(\mu \mathrm{molCO}_{2} \mathrm{~m}^{-2} \mathrm{~s}^{-1}\right)\end{array}$ & $\begin{array}{c}\text { Leaf conductance } \\
\left(\mathrm{molH}_{2} \mathrm{Om}^{-2} \mathrm{~s}^{-1}\right)\end{array}$ & $\begin{array}{c}\text { Transpiration rate } \\
\left(\mathrm{molH}_{2} \mathrm{Om}^{-2} \mathrm{~s}^{-1}\right)\end{array}$ \\
\hline Degree of defoliation & & & $3.24 \mathrm{f}$ \\
Control (not defoliated $)$ & $22.0 \mathrm{~g}$ & $0.23 \mathrm{e}$ & $3.40 \mathrm{e}$ \\
$50 \%$ basal leaves & $23.0 \mathrm{~d}$ & $0.24 \mathrm{~d}$ & $4.44 \mathrm{a}$ \\
$100 \%$ defoliation & $27.2 \mathrm{a}$ & $0.28 \mathrm{a}$ & $4.13 \mathrm{~b}$ \\
$50 \%$ top leaves & $26.1 \mathrm{~b}$ & $0.26 \mathrm{~b}$ & $3.91 \mathrm{c}$ \\
Top 4 leaves & $25.4 \mathrm{c}$ & $0.25 \mathrm{c}$ & $3.78 \mathrm{~d}$ \\
Top 3 leaves & $22.8 \mathrm{de}$ & $0.25 \mathrm{c}$ & $3.45 \mathrm{e}$ \\
Top 2 leaves & $22.6 \mathrm{ef}$ & $0.24 \mathrm{~d}$ & $3.41 \mathrm{e}$ \\
Top 1 leaf & $22.4 \mathrm{f}$ & $0.23 \mathrm{e}$ & \\
Genotypes & & & 3.72 \\
BARI Soybean-5 & $24.1 \mathrm{a}$ & 0.25 & 3.73 \\
BAU Soybean-109 & $23.9 \mathrm{~b}$ & 0.25 & 3.71 \\
AVDRC Soybean-78 & $23.8 \mathrm{~b}$ & 0.25 & 3.71 \\
BAU Soybean-147 & $23.9 \mathrm{~b}$ & 0.25 & \\
Year & & & 3.69 \\
2010 & 23.9 & 0.24 & 3.75 \\
2011 & 24.0 & 0.25 & 3.22 \\
CV\% & 2.17 & 4.41 & \\
\hline
\end{tabular}

Values having common letter(s) in a column do not differ significantly at 5\% level as per DMRT.

Table 2. Effects of defoliation on dry matter production and distribution of soybean genotypes.

\begin{tabular}{lcllcc}
\hline Treatment & $\begin{array}{c}\text { Root wt. } \\
(\mathrm{g})\end{array}$ & $\begin{array}{c}\text { Stem wt. } \\
(\mathrm{g})\end{array}$ & $\begin{array}{c}\text { Leaf wt. } \\
(\mathrm{g})\end{array}$ & $\begin{array}{c}\text { Pod wt. } \\
(\mathrm{g})\end{array}$ & $\begin{array}{c}\text { Total dry matter } \\
\text { /plant }(\mathrm{g})\end{array}$ \\
\hline Degree of defoliation & & & & & \\
Control (not defoliated) & $1.73 \mathrm{a}$ & $10.09 \mathrm{a}$ & $5.94 \mathrm{a}$ & $15.27 \mathrm{a}$ & $33.05 \mathrm{a}$ \\
$50 \%$ basal leaves & $1.46 \mathrm{e}$ & $6.81 \mathrm{c}$ & $3.61 \mathrm{c}$ & $11.72 \mathrm{c}$ & $23.61 \mathrm{~d}$ \\
$100 \%$ defoliation & $1.16 \mathrm{~h}$ & $3.98 \mathrm{e}$ & $2.98 \mathrm{de}$ & $7.47 \mathrm{~g}$ & $15.61 \mathrm{~g}$ \\
$50 \%$ top leaves & $1.27 \mathrm{~g}$ & $5.01 \mathrm{a}$ & $2.45 \mathrm{e}$ & $8.30 \mathrm{f}$ & $17.05 \mathrm{f}$ \\
Top 4 leaves & $1.40 \mathrm{f}$ & $8.04 \mathrm{~b}$ & $3.21 \mathrm{~cd}$ & $9.70 \mathrm{e}$ & $22.36 \mathrm{e}$ \\
Top 3 leaves & $1.50 \mathrm{~d}$ & $8.23 \mathrm{~b}$ & $3.39 \mathrm{~cd}$ & $11.41 \mathrm{~d}$ & $24.53 \mathrm{c}$ \\
Top 2 leaves & $1.58 \mathrm{c}$ & $10.38 \mathrm{a}$ & $4.46 \mathrm{~b}$ & $14.91 \mathrm{~b}$ & $31.35 \mathrm{~b}$ \\
Top 1 leaf & $1.63 \mathrm{~b}$ & $10.15 \mathrm{a}$ & $4.24 \mathrm{~b}$ & $15.19 \mathrm{a}$ & $31.23 \mathrm{~b}$ \\
Genotypes & & & & & \\
BARI Soybean-5 & $1.41 \mathrm{c}$ & $7.83 \mathrm{~b}$ & $3.12 \mathrm{~b}$ & $12.33 \mathrm{~b}$ & $24.70 \mathrm{~b}$ \\
BAU Soybean-109 & $1.52 \mathrm{a}$ & $7.71 \mathrm{~b}$ & $4.42 \mathrm{a}$ & $11.39 \mathrm{c}$ & $25.05 \mathrm{~b}$ \\
AVDRC Soybean-78 & $1.44 \mathrm{~b}$ & $5.65 \mathrm{c}$ & $2.99 \mathrm{~b}$ & $10.27 \mathrm{~d}$ & $20.37 \mathrm{c}$ \\
BAU Soybean-147 & $1.51 \mathrm{a}$ & $10.16 \mathrm{a}$ & $4.60 \mathrm{a}$ & $12.99 \mathrm{a}$ & $29.27 \mathrm{a}$ \\
Year & & & & & \\
2010 & 1.41 & 8.00 & 3.72 & 11.73 & 24.87 \\
2011 & 1.53 & 7.67 & 3.85 & 11.76 & 24.82 \\
CV\% & 2.92 & 10.02 & 30.17 & 4.75 & 5.99 \\
\hline
\end{tabular}

Values having common letter(s) in a column do not differ significantly at 5\% level as per DMRT. 
Dry matter production was severely affected by $100 \%$ defoliation followed by $50 \%$ defoliation of top leaves. BAU Soybean-147 showed the highest and AVRDC Soybean-78 the least total dry matter. The higher leaf loss compensation capacity could be due to initial leaf area and hence, the remaining leaf after defoliation along with initials and newly emerged leaves together was capable to produce greater total dry matter by increasing photosynthesis (Rao and Ghildiyal 1985). Yield was decreased with all defoliation treatments except defoliation of top one and two leaves (Table 3). Soybean yields were found to be identical under these two treatments compared to the control. BARI Soybean-5 showed the highest and AVRDC Soybean-78 produced the least yield.

Table 3. Effect of defoliation on yield attributes and yield of soybean genotypes.

\begin{tabular}{lcccc}
\hline Treatment & $\begin{array}{c}\text { Number of } \\
\text { pods/plant }\end{array}$ & $\begin{array}{c}\text { Number of } \\
\text { seeds/pod }\end{array}$ & $\begin{array}{c}1000 \text {-seed } \\
\text { wt. }(\mathrm{g})\end{array}$ & $\begin{array}{c}\text { Yield/plant } \\
(\mathrm{g})\end{array}$ \\
\hline Degree of defoliation & & & & \\
Control (not defoliated) & $38.68 \mathrm{a}$ & $3.72 \mathrm{~b}$ & $82.37 \mathrm{a}$ & $11.73 \mathrm{a}$ \\
$50 \%$ basal leaves & $32.90 \mathrm{c}$ & $3.40 \mathrm{c}$ & $81.00 \mathrm{bc}$ & $9.10 \mathrm{~b}$ \\
$100 \%$ defoliation & $22.90 \mathrm{f}$ & $3.28 \mathrm{~d}$ & $81.06 \mathrm{bc}$ & $6.09 \mathrm{f}$ \\
$50 \%$ top leaves & $26.37 \mathrm{e}$ & $3.12 \mathrm{e}$ & $80.53 \mathrm{c}$ & $6.66 \mathrm{e}$ \\
Top 4 leaves & $30.56 \mathrm{~d}$ & $3.11 \mathrm{e}$ & $80.50 \mathrm{c}$ & $7.64 \mathrm{~d}$ \\
Top 3 leaves & $34.00 \mathrm{c}$ & $3.24 \mathrm{~d}$ & $80.90 \mathrm{bc}$ & $8.88 \mathrm{c}$ \\
Top 2 leaves & $37.43 \mathrm{~b}$ & $3.89 \mathrm{a}$ & $81.81 \mathrm{ab}$ & $11.85 \mathrm{a}$ \\
Top 1 leaf & $38.18 \mathrm{ab}$ & $3.87 \mathrm{a}$ & $80.87 \mathrm{bc}$ & $11.78 \mathrm{a}$ \\
Genotypes & & & & \\
BARI Soybean-5 & $35.12 \mathrm{a}$ & $3.55 \mathrm{a}$ & 81.51 & $10.08 \mathrm{a}$ \\
BAU Soybean-109 & $31.81 \mathrm{~b}$ & $3.41 \mathrm{~b}$ & 81.45 & $9.05 \mathrm{c}$ \\
AVDRC Soybean-78 & $28.03 \mathrm{c}$ & $3.46 \mathrm{~b}$ & 80.78 & $7.99 \mathrm{~d}$ \\
BAU Soybean-147 & $35.56 \mathrm{a}$ & $3.40 \mathrm{~b}$ & 80.78 & $9.75 \mathrm{~b}$ \\
Year & & & & \\
2010 & 32.14 & 3.43 & 81.65 & 9.08 \\
2011 & 33.11 & 3.48 & 80.60 & 9.35 \\
CV\% & 7.35 & 6.70 & 2.78 & 4.53 \\
\hline
\end{tabular}

Values having common letter(s) in a column do not differ significantly at $5 \%$ level as per DMRT.

Defoliation treatments decreased yield in soybean in following order as $100 \%$ defoliation, $50 \%$ defoliation of top leaves, defoliation of top 4 leaves, defoliation of top 3 leaves, $50 \%$ defoliation of basal leaves and defoliation of top 1 or 2 leaves did not affect yield. With defoliation of either 1 or 2 top leaves, yield production remained same as compared to undefoliated control. This indicates that physiological mechanisms might have rejuvenalized just after defoliations by defoliation of either 1 or 2 top leaves threshold level by initiating new leaves and could be one of the reasons that compensated this leaf loss.

\section{References}

Abdi S, Fayaz MA and Chadimzade M 2007. Effect of different levels of defoliation at reproductive stage on grain yield and oil per cent of two hybrid sunflower. Agric. Nat. Res. Sci. Tech. 11: 245-255. 
Banks LW and Bernardi AL 1987. Growth and yield of indeterminate soybeans. 1. Effect of defoliation. Aust. J. Exp. Agric. 27(6): 889-895.

Barimavandi AR, Sedaghathoor S and Ansari R 2010. Effect of different defoliation treatments on yield and yield components in maize cultivation of SC704. Aust. J. Crop Sci. 4(1): 9-15.

Begum M, Hamid A, Sultana W and Khan MR 1997. Effect of defoliation on yield and yield contributing characters of mungbean in relation to nodal position and position of seeds in pod. Bangladesh J. Agric. Res. 22: 43-50.

Bernacchi CJ, Kimball BA, Quarles DR, Long SP and Ort DR 2007. Decreases in stomatal conductance of soybean under open-air elevation of $\mathrm{CO}_{2}$ are closely coupled with decreases in ecosystem evapotranspiration. Plant Physiol. 143: 134-144.

Bhatt RM and Rao NKS 2003. Influence of leaf excision on photosynthesis, seed setting and yield in okra. Indian J. Plant Physiol. 8: 345-348.

Board JE and Harville BG 1998. Late planted soybean yield response to reproductive source-sink stress. Crop Sci. 38: 763-771.

Borras L, Slafer GA and Otegui ME 2004. Seed dry weight response to source-sink manipulations in wheat, maize and soybean: a quantitative reappraisal. Field Crops Res. 86:131-146.

Chen CY and Lia WSI 1991. Effects of source-sink alteration on stomatal movement in different soybean cultivars. Photosynthetica. 25: 437-439.

Chhabra ML, Yadava, Kiran TP and Kapoor K 1996. Effect of partial defoliation on productivity in Indian mustard. Cruciferae Newsl. 18: 48-49.

Ghosh BK and Sengupta UK 1986. Effect of source manipulation on photosynthetic activity in groundnut. Indian J. Plant Physiol. 29: 351-356.

Gustafson TC, Knezevic SZ, Hunt TE and Lindquist JL 2006. Stimulated insect defoliation and duration of weed interference affected soybean growth. Weed Sci. 54: 735-742.

Hossain MA, Haque MA, Chowdhury S and Fakir MSA 2006. Effect of defoliation on morphological characters, dry mass production and seed yield in cowpea. J Bangladesh Soc. Agric. Sci. Technol. 3: 197-200.

Islam MT 2010. Effect of detopping, defoliation and deflowering on photosynthesis and yield parameters of non-branching sesame (Sesamum indicum L.). Int. J. Sustain. Crop Prod. 5: 11-15.

Kokilavani S, Jagannathan R, Selvaraju R and Thavaprakaash N 2007. Influence of terminal clipping on growth and yield of sesame varieties. Asian J. Agric. Res. 1: 142-145.

Pandey PK 1983. Influence of defoliation on seed yield in cowpea [Vigna unguiculata (L.) Walp.] in a subtropical environment. Field Crops Res. 7: 249-256.

Pandey RK and Singh VB 1984. Influence of source and sink size on growth and seed yield of mungbean [Vigna radiata]. Legume Res. 7: 27-36.

Proulx RA and Naeve SL 2009. Pod removal, shade, and defoliation effects on soybean yield, protein, and oil. Agron. J. 101: 971-978.

Rao TRT and Ghildiyal MC 1985. Analysis of photosynthetic source and sink relationship in mungbean. Indian J. Plant Physiol. 28: 135-144..

Tewolde H, Mulley JR and Fernandez CJ 1994. Recovery of sesame from defoliation and growth terminal clipping. Agron. J. 86: 1060-1065.

Venkateswarlu B and Visperas RM 1987. Source-sink relationships in crop plants. IRRI Res. paper series 125: 1-19.

Verma R, Awasthi AK and Chowdhary BS 1992. Effect of artificial defoliation on plant growth and seed weight of soybean. Indian J. Agric. Sci. 62: 290-292.

(Manuscript received on 12 November, 2012; revised on 27 August, 2013) 